\title{
Determinants of Commercial Banks Credit to the Domestic Economy in Nigeria: Examinations of Dynamics Principles
}

\author{
Akani, Henry Waleru ${ }^{1} \&$ Oparaordu, Beauty ${ }^{1}$ \\ ${ }^{1}$ Department of Banking and Finance, Rivers State University, Nkpolu-Port Harcourt, Rivers State, Nigeria \\ Correspondence: Akani, Henry Waleru, Department of Banking and Finance, Rivers State University, Nkpolu-Port
}

Harcourt, Rivers State, Nigeria

Received: July 20, 2018

Accepted: July 28, 2018

Online Published: August 8, 2018

\begin{abstract}
This study examined determinants of commercial banks credit to the domestic economy in Nigeria. The objective was to examine the extent to which banks variables, macroeconomic and monetary policy variables affects credit allocation of Nigerian Commercial Banks. Time series data was sourced from Central Bank of Nigeria Statistical bulletin and financial statement of commercial banks. Percentage of total commercial banks loans to gross domestic product was proxy for dependent variable while the banks specific variables are peroxide by operational efficiency, liquidity, number of commercial banks branches, Commercial Banks Deposit Liabilities and deposit rate. The independent variables in macroeconomic model comprises of real gross domestic product, public expenditure, openness of the economy, inflation rate and exchange rate while monetary policy variables comprises of treasury bills rate, real interest rate, monetary policy rate, growth of money supply and financial sector development. The study employed ordinary least square properties of augmented Dickey Fuller test, co-integration test, and granger causality test and vector error correction model. Findings from the study revealed that; banks specific variables shows that deposit liabilities and liquidity ratio have positive impact on total loans and advances while deposit rate, number of commercial banks branches and openness of the economy have negative impact. Model II found that; exchange rate, inflation rate and Real Gross Domestic Product have positive impact while public expenditure and openness of the economy have negative impact on total commercial bank loans and advances. Model III found that; financial sector development and monetary policy rate have negative impact while growth of money supply, real interest rate and Treasury bills rate have positive impact on total loans and advances of commercial banks. We conclude that monetary policy, bank specific variables or internal variables and macroeconomic variables are strong determinants of Nigerian commercial banks loans and advances. We therefore, recommend for the interplay and the strengthening of macroeconomic variables, monetary policy variables and banks specific variables (internal policies) in order to enhance commercial banks credit in Nigeria.
\end{abstract}

Keywords: Determinants, Bank Credit, Domestic Economy, Macroeconomic Variables, Monetary Policy Variables and Banks Specific Variables.

\section{Introduction}

In a deregulated, monopolistically competitive and oligopolistic banking environment like Nigeria, bank credit is determined by internal and external factors. From the internal factors, commercial banks credit is determined by capital adequacy, number of bank branches, commercial banks deposit liabilities, operational efficiency and deposit rate. From the monetary policy perspective, commercial banks' lending depend on monetary policy rate, treasury bill rate real interest rate, financial development and growth of money supply while macroeconomic variables includes commercial banks' lending which depends on growth of the economy, inflation rate, real exchange rate, openness of the economy and public expenditure. Credit is a financial market activity where financial institutions are empowered by law with credit functions to extend credit facilities to deficit economic units. The monetary 
authorities use credit policies to achieve macroeconomic growth. For instance, credit policies are used to achieve growth in some sectors of the economy, (Akani and Onyema, 2017).

Bank loans are one of the most important long-term financing sources in many countries. Commercial banks are the most important savings mobilization and financial resource allocation institutions. Consequently, these roles make them an important phenomenon in economic growth and development. In performing this role, it must be realized that banks have the potential, scope and prospects for mobilizing financial resources and allocating them to productive investments. Olokoyo(2011), further notes that no matter the sources of the generation of income or the economic policies of the country, commercial banks would be interested in giving out loans and advances to their numerous customers bearing in mind, the three principles guiding their operations which are, profitability, liquidity and safety. Lending institutions play a major role in economic growth and development through provision of credit to execute economic activities.

Lending which may be on short, medium or long-term basis is one of the services that commercial banks do render to their customers. In other words, banks do grant loans and advances to individuals, business organizations as well as government in order to enable them embark on investment and development activities as a mean of aiding their growth in particular or contributing toward the economic development of a country in general. Commercial banks are the most important savings mobilization and financial resource allocation institutions. Consequently, these roles make them a vital tool in economic growth and development. In performing this role, it must be realized that banks have the potential, scope and prospects for mobilizing financial resources and allocating them to productive investments.

Lending practices in the world could be traced to the period of industrial revolution which increase the pace of commercial and production activities thereby bringing about the need for large capital outlays for projects. However, the emergence of banks in Nigeria in 1872 with the establishment of the African Banks Corporation (ABC) and later appearance of other banks in the scene during the colonial era witnessed the beginning of banks' lending practice in Nigeria. Though, the lending practices of the then colonial banks were biased and discriminatory and could not be said to be a good lending practice as only the expatriates were given loans and advances. ( Amadi and Akani, 2004). The Bank and Other Financial Act Amendment (BOFIA) 1998, requires banks to report large borrowing to the Central Bank of Nigeria. The Central Bank of Nigeria also require that their total value of a loan credit facility or any other liability in respect of a borrower, at any time, should not exceed $20 \%$ of the shareholders' funds unimpaired by losses in the case of commercial banks. Other banking enactment stipulated that banks loans should be directed to preferred sector of the economy in order to enhance economic growth and development. In full consideration of all these regulations the banks resorted to prudential guidelines necessary to avoid failures and to enhance maximum profitability in their banks' lending activities.

Empirical and theoretical evidence shows that there is a relationship between commercial banks credit and factors that determined commercial banks' lending. The study of Akani and Onyema(2017) examined factors that determine credit growth in the economy, the study used net domestic credit, and this implies that, the study goes beyond commercial banks and other financial institutions that undertake the functions of lending and borrowings. Olokoyo(2011) does not disaggregated the factors based on macroeconomic, bank internal variables and monetary variables, the result therefore does not validate the effects of monetary, macroeconomic and internal policies variables on commercial banks' lending in Nigeria. From the above knowledge gap, this study examined the determinants of commercial banks 'credit to the domestic economy of Nigeria by disaggregating the variables into internal, monetary and macroeconomic variables.

\section{Literature Review}

\section{Conceptual Foundation \\ Concept of Bank Lending}

Lending which is considered to be the main function of banks in general and commercial banks, in particular, could be on a short, medium and long-term basis. It is the act of making funds available with the hope of receiving back the principal plus interest payment or/and any other fees imposed on carrying out the transaction. Credit is a financial market activity where financial institutions are empowered by law with credit functions to extend credit facilities to deficit economic units.

\section{Theories of Bank Credit}

\section{Loan Pricing Theory}

Banks cannot always set high interest rates and trying to earn maximum interest income. Banks should consider the problems of adverse selection and moral hazard since it is very difficult to forecast the borrower type at the start of the banking relationship (Oputu, 2010). If banks set interest rates too high, they may induce adverse selection problems because high-risk borrowers are willing to accept these high rates. Once these borrowers receive the loans, they may develop moral hazard behaviour or so called borrower moral hazard since they are likely to take on highly 
risky projects or investments (Chodecai, 2004). From the reasoning of Stiglitz and Weiss, it is usual that in some cases we may not find that the interest rate set by banks is commensurate with the risk of the borrowers.

\section{Firm Characteristics Theories}

These theories predict that the number of borrowing relationships will be decreasing for small, high-quality, informational opaque and constraint firms, all other things been equal. (Godlewski\&Ziane, 2008)

\section{Theory of Multiple-Lending}

Literatures explain that banks should be less inclined to share lending (loan syndication) in the presence of welldeveloped equity markets and after a process consolidation. Both outside equity and mergers and acquisitions increase banks' lending capacities, thus reducing their need of greater diversification and monitoring through share lending. Degryse et al (2004). This theory has a great implication for banks in Nigeria in the light of the recent 2005 consolidation exercise in the industry.

\section{Hold-up and Soft-Budget-Constraint Theories}

Banks choice of multiple-bank lending is in terms of two inefficiencies affecting exclusive bank-firm relationships, namely the hold-up and the soft-budget-constraint problems. According to the hold-up literature, sharing lending avoids the expropriation of informational rents. This improves firms' incentives to make proper investment choices and in turn it increases banks' profits (Von Thadden, 2004; Padilla and Pagano, 1997). As for the soft-budgetconstraint problem, multiple-bank lending enables banks not to extend further inefficient credit, thus reducing firms' strategic defaults. Both of these theories consider multiple-bank lending as a way for banks to commit towards entrepreneurs and improve their incentives. None of them, however, addresses how multiple-bank lending affects banks' incentives to monitor, and thus can explain the apparent discrepancy between the widespread use of multiplebank lending and the importance of bank monitoring. But according to Carletti et al (2006), when one considers explicitly banks' incentives to monitor, multiple-bank lending may become an optimal way for banks with limited lending capacities to commit to higher monitoring levels. Despite involving free-riding and duplication of efforts, sharing lending allows banks to expand the number of loans and achieve greater diversification. This mitigates the agency problem between banks and depositors, and it improves banks' monitoring incentives. Thus, differently from the classical theory of banks as delegated monitors, their paper suggested that multiple-bank lending may positively affect overall monitoring and increase firms' future profitability.

\section{The Signaling Arguments}

The signaling argument states that good companies should provide more collateral so that they can signal to the banks that they are less risky type borrowers and then they are charged lower interest rates. Meanwhile, the reverse signaling argument states that banks only require collateral and or covenants for relatively risky firms that also pay higher interest rates (Chodechai, 2004; Ewert and Schenk, 1998).

\section{Credit Market Theory}

A model of the neoclassical credit market postulates that the terms of credits clear the market. If collateral and other restrictions (covenants) remain constant, the interest rate is the only price mechanism. With an increasing demand for credit and a given customer supply, the interest rate rises, and vice versa. It is thus believed that the higher the failure risks of the borrower, the higher the interest premium (Ewert et al, 2000).

\section{Empirical Literature}

Akani and Onyema (2017), examined the determinants of credit growth in Nigeria. Annual time series data were sourced from Central Bank of Nigeria statistical bulletin from 1981-2016.Three multiple regression models were formulated to examine the effect of macroeconomic variables, monetary policy variables and international variables on the growth of Nigeria's net domestic credit. The unit root test indicates that all the variables are stationary at first difference using the Augmented Dickey Fuller (ADF) test. The Johansen Cointegration test result shows that there exists a positive long run dynamic relationship between the dependent and the independent variables. TheGranger causality test shows a uni-variate relationship from the independent to the dependant variable. From the macroeconomic variable, public expenditure, inflation rate and capital formation have a negative relationship with growth of Nigeria net domestic credit while real gross domestic product, government revenue and balance of payment have a positive impact on the dependent variable, we conclude that macroeconomic variables have significant effect on the growth of Nigeria's net domestic credit. From the monetary policy variables, treasury bill rate, interest rate and compliance to credit rules have a negative effect on net domestic credit while monetary policy rate, financial deepening and growth of broad money supply have a positive effect on the dependent variables. We also conclude that monetary policy variables have no significant relationship with the growth of net domestic credit in Nigeria. While from the international variables, exchange rate, international liquidity, foreign direct investment and openness of the economy have positive effect on net domestic credit whereas cross boarder credit and net foreign portfolio investment have negative relationship with net domestic credit. From the result, we conclude that international variables have no significant relationship with the growth of net domestic credit in Nigeria. 
Gertler and Gilchrist (1994) on how bank business lending responds to monetary policy tightening, the study reveals that business lending does not decline when policy is tightened. They concluded that the entire decline in total lending comes from a reduction in consumer and real estate loans. Kashyap and Stein (1995) find evidence that business lending may respond to a tightening of monetary policy. They find that when policy is tightened, both total loans and business loans at small banks fall, while loans at large banks are unaffected. The differential response of small banks may indicate they have less access to alternative funding sources than large banks and so are less able to avoid the loss of core deposits when policy is tightened.

Gambacorta and Iannoti (2005) studied the velocity and asymmetry in response of bank interest rates (lending, deposit, and inter -bank) to monetary policy shocks (changes) from 1985-2002 using an Asymmetric Vector Correction Model (AVECM) that allows for different behaviours in both the short-run and long-run. The study shows that the speed of adjustment of bank interest rate to monetary policy changes increased significantly after the introduction of the 1993 Banking Law, interest rate adjustment in response to positive and negative shocks are asymmetric in the short run, with the idea that in the long -run the equilibrium is unique. They also found that banks adjust their loan (deposit) prices at a faster rate during period of monetary

Van den Heuvel (2005) in his study shows that monetary policy affects bank lending through two channels. They argued that by lowering bank reserves, contractionary monetary policy reduces the extent to which banks can accept reservable deposits, if reserve requirements are binding. The decrease in reservable liabilities will, in turn, lead banks to reduce lending, if they cannot easily switch to alternative forms of finance or liquidate assets other than loans.

Punita and Somaiya (2009) examined the impact of monetary policy on profitability of banks in India between 1995 and 2000 provided some dissenting evidence that lending rate has a positive and significant influence on banks' profitability, which indicates a fall in lending rates will reduce the profitability of the banks. It was also found out that bank rate, cash reserve ratio and statutory ratio significantly affect profitability of banks negatively. Their findings were the same when lending rate, bank rate, cash reserve ratio and statutory ratio were pooled to explain the relationship between bank profitability and monetary policy instruments in the private sector.

Amidu and Wolfe (2008) examined the constrained implication of monetary policy on bank lending in Ghana between 1998 and 2004. Their study revealed that Ghanaian banks' lending behaviour are affected significantly by the country's economic also support and change in money supply. Their findings also support the finding of previous studies that the central bank prime rate and inflation rate negatively affect bank lending. Prime rate was found statistically significant while inflation was insignificant. Based on the firm level characteristics, there study revealed that bank size and liquidity significantly influence bank's ability to extend credit when demanded.

Somoye and Ilo (2009) investigated the impact of macroeconomic instability on the banking sector lending behaviour in Nigeria between 1986 to 2005. Their study revealed the mechanism transmission of monetary policy stocks to banks operation. The result of cointegration and Vector Error correction suggests a long-run relationship between bank lending and macroeconomic instability. This study will empirically analyze the effect of monetary policy on the commercial banks' lending in Nigeria with the intension of determining the influence of monetary policy instruments on commercial bank loan and advances.

TUhomoibhi (2008) investigated the determinants of bank profitability macroeconomic evidence from Nigeria seeking to econometrically identify significant using a panel data set comprising 1255 observations of 154 banks over a period of 1980-2006, the indices over the same period regression result reveal that interest rate, inflation, monetary policy and exchange rate regime, significant macroeconomic determinants of banks profitability in Nigeria banking sector development, stock market development and financial structure are insignificant and the relationship between corporate tax policy and bank profitability in Nigeria is inconclusive. In

Samad (2004) examined the study of Bahrans commercial banks performances during 1994-2001. The main focus of the study was to examine empirically the performance of Bahrains commercial banks with respect to credit (loan), liquidity and profitability during the period. By applying students'-test to the financial measure, it was shown that commercial banks liquidity performance is not at par with the banking industry. That is commercial banks are relatively less profitable and less liquid as expected.

Although Chizea (1994) asserted that, there are certain aspects of fiscal and monetary policies which could affect the decision of the discerning and informed public to patronize the bank and the lending behaviour of commercial banks. Paramount amongst these measures is what could be called the interest rate disincentives. Interest rates have been so low in the country that they are negative in real terms. As inflation increased, the purchasing power of money lodged in deposit accounts reduce to the extent that savers per force pay an inflation tax. There is also the fear that the hike in interest rates would increase inflations rates and make a negative impact on the rate of investment. 
Naceur and Goaid (2010) investigated the determinants of commercial banks interest margin and profitability (evidence from Tunisia). The study received the impact of banks characteristics, financial structure and macroeconomic indicators on bank's net interest margin and profitability in Tunisia banking sector for the period of 1980-2000. It shows that individual bank characteristic explains a substantial part of the within country variation in bank interest margin and net profit. High net interest margin and profitability tend to be associated with banks that hold a relatively high amount of capital and with large overheads size is found to impact negatively on profitability which implies that Tunis banks are operating above their optimum level.

William (2009) will result to a near shut down in lending ratio volume to any bank with major credit concern because, new policy ensures that only the highest quality borrowers have access to a new bank credit within the year, but according to Ojo (1999) in a study on "roles and failure of financial intermediation by banks in Nigeria revealed that commercial banks can lend on medium and short term basis without necessarily jeopardizing their liquidity. If they must contribute meaningfully to the economic development, the maturity pattern of their loans should be on a long term nature rather than of short term period.

Davis and Zhu (2005) examined the study of commercial property prices and bank performance during the 19892002 periods. This paper seeks to fill the gap by undertaking an extensive analysis of a sample of 904 banks worldwide. It seeks to assess the effect of changes in commercial property prices on bank behaviour and performances in 15 industrialized economies. The result of this study suggest that commercial property price tend to be positively associated with bank lending and profitability, negatively associated with banks net interest margin, bad loan ratios. Such impact exists even when conventional independence variable determining banks performance are included as controls.

Olokoya(2011) claimed in the study on the common determinants of commercial banks lending behavior in Nigeria which aimed to test and confirm the effectiveness of these factors/variables. It reveals that there exists functional relationship between the variables. From the regression analysis, the model was found to be significant and its estimators turned out as expected and it was discovered that commercial banks have greatest impact on their lending behavior. And suggested that commercial banks should focus on mobilizing more deposits, as it will enhance their lending performance through the formulation of critical, realistic and comprehensive strategies and financial plans Though Acha (2011) probed into ,the effect of banks financial intermediation on economic growth on a time frame of $1980-2008$, adopting the Granger causality test to ascertain the relationship that exist between savings mobilization and credit on one hand and economic growth on the other. Osayameh (1991) supported this veiw by stressing that the days of arm chain banking are over, and that the increasing trend in bad debts and absence of basic business corporate advisory services in most Nigerian commercial banks, suggest an apparent lack of use of effective lending and credit administration technique in these banks.

Buccheit (1992) in his study based on Syndicated loans found out that when commercial banks jointly give out loans to a borrower, they are able to efficiently minimize their cost and manage time. They can better deliberate with the borrower(s) concerning the loan agreement for their various organizations. In addition, this paves the way for a constant follow-up of these borrowers to avoid default.

Eichengreen et al (1998) believed that commercial banks will not hesitate to give out loans if they can effectively deal with the problem of asymmetric information through constant surveillance. Also, if they are able to mitigate lending risks to a greater extent by diversifying their portfolio assets and maximize their profits. Kashyap et al (1997) commercial banks would be willing to lend to individuals whose information are not perfect. This is because these firms will solely depend on the banks for their financial needs. In this case, the banks can exercise their full rights over them and obtain the necessary information to know if they will be able to meet their debt obligation. Moreover, with the information at hand, these banks will be efficient and guided in making good lending decisions. Ahiawodzi and Sackey (2013) banks use different strategies to assess their credit and it is vital for them to consider these guiding rules in carrying out their lending activities. This is because commercial banks do not trust the information they acquire from opaque borrowers who might end up defaulting. Some recent researchers found out that in addition to a political and environmental crisis, the banking crisis is also a major hindrance to the economic growth of countries. One way to tackle this issue is to implement or set up strict rules and regulations to govern banks' lending activities. This policy does not only reduce the cost of the crisis in a society, but it as well enables banks to better maximize their profits and boost up economic growth (Quintyn et al., 2003).

Daniel and Jones (2007) carried out a study based on financial liberalizationand Banking crisis in emerging countries were of the opinion that some causes ofthe financial crisis occurred because some banking systems were not well coordinated. They believed that a proper supervision of these banks would have permitted a good number of countries to experience a grace period of minimum risk followed with economic development before the outburst of the crisis. In South Africa, commercial banks do not easily make loans available to SMEs and less privileged individuals in the society. 
Kumbirai et al (2013) did a study for the case of South Africa on "Banks' ratio analysis performance discovered that in the process of meeting up with the 1994 constitutional democracy, the South African commercial banks had to experience series of updates in their regulatory policies. Gilbert et al (2009)supported this view by saying that "the implementation of these rules and regulations for banks was purposely done to bring about the equality across a nonvolatile financial domain and to curb the rising competition costs through regulatory requirements, innovation and new technologies during the financial crisis. The financial crisis that occurred in recent years, negatively affected every part of the world, particularly in South Africa. Banks were not only reluctant to lend to one another, but became even more unwilling to give out loans to SMEs and individuals.

Djiogap and Ngomsi (2012) carried out a study for the period of 2001-2010 on factors that influences banks' Lending Behavior in the Central African Economic and Monetary Community on long-term basis. Six countries in the CEMAC zone and 35 commercial banks were considered. Using a panel data analysis, they found out that bank's capital to asset ratio, long- term liabilities, GDP growth and its size were statistically significant. This implies that these variables are taken into consideration by banks in making long-term loans available to firms. They also carried out a multivariate test based on different countries which revealed that banks with inadequate capital, high non-performing loans and small banks functions.

Olokoyo (2011) examined this topic for the case of the Nigerian Economy for the period of 1980-2005. From her findings, the predictor variables (volume of deposits, investment portfolio, foreign exchange, and GDP) were statistically significant and portrayed a positive relationship with commercial bank lending. This implies that these explanatory variables are very vital for banks' lending decisions to give out loans and advances to borrowers. She suggested that commercial banks in Nigeria should improve their management skills and lending performance by building up new strategies and system that will pull deposits irrespective of its source.

Panagopoulos and Spiliotis (1998) for the period of 1971-1993 also carried out a dissertation on the influencing factors of commercial banks' lending decision in Greece and made use of the panel software analysis and regression model. Their findings exhibited that credit money, money wage bill, and loan customer relation had a strong significant impact on commercial banks' lending behavior in Greece. These researchers asserted that "statistically it is senseless for Greek monetary authorities to keep pressurizing commercial banks to reserve a large percentage of their deposits in risk-free assets such as T-bills. They suggested that the Greek monetary authorities should set the maximum amount of bank's lending rate. Malede (2014), examined the determinants of commercial banks' Lending in Ethiopia over a 6-year period (2005-2011). He applied the panel data analysis and OLS to find out that credit risk, bank size, GDP, liquidity, lending rate and investment were statistically significant and had a positive relationship with commercial banks' lending. He concluded that these explanatory variables greatly influenced banks' lending decisions compared to deposit and cash required reserve which was insignificant. He suggested that commercial banks should throw more light on their credit risk and better manage their liquidity ratio because these variables prevent their willingness to lend.

Tomak (2013) investigated on this topic for the case of Turkey starting from the period 2003-2012 considering 18 banks for the sample size. His results showed that GDP and interest rate were statistically insignificant. On the other hand, banks total liabilities, NPL size and inflation rate were statistically significant and had a positive relationship with commercial banks' lending behavior. Chodechai (2004), in his study on the "Determinants of bank lending in Thailand" supported Cole's second view about past relationships as a criterion in banks' lending decision. He discovered that when banks have such relationships with borrowers, they are more confident in accessing the borrowers' privacy concerning their occupations and their financial state at every point in time.

Cole (1998) found out that commercial banks, unlike other lending institutions are very unwilling to give out loans. The reason is because during the period of the 1990s these lenders were pressurized by their regulators to make underwriting benchmark or requirement difficult to attain or meet up with. He further stressed that these banks would consider making credit available to firms with whom they have had a close relationship no matter how long. In addition to that, if they are informed about them being the sole providers of financial services to these firms, they will be willing to lend.

Loutskina (2011), in her research study on the role of securitization in bank liquidity and funding management she found out that when banks are able to liquidate their loans in order to meet their liquidity needs, they will be more willing to make credit available to borrowers. According to her, since liquid funds and loans are very vital elements of bank assets there is a negative relationship between liquid funds and lending. That is to say, as the former decreases the later increases. This paragraph discusses the view of researchers under category 4 as specified in the 1st paragraph above. Behr et al (2013) carried out investigations on financial constraints of Private firms" and discovered that banks' lending behavior are influenced by soft information based on the quality of the borrower and continuous lending relationship. Ahiawodzi and Sackey (2013) investigated the rationing behavior of some commercial lending in Ghana. Their results displayed that experience, security value; sex, net profit, purpose, and 
age were significant in determining the amount of loan given out. Imran and Nishat (2013) empirically identified commercial banks credit lending in Pakistanfor the period 1971-2010. From their findings domestic deposits, exchange rate, foreign liabilities, greatly influenced banks' lending decisions to the private sector in the long run. Inflation has an insignificant role in the long run. Also, domestic deposits in the short run do not apply with private credit because banks do not loan from the current account deposit.

3. Research Methodology

This study used quasi experimental research design approach for the data analysis. The data for this study are secondary data sourced from the Central Bank of Nigeria Statistical Bulletin, Stock Exchange Fact book, Economic and Financial Review and Financial Statement of quoted commercial banks. From theories, principles and empirical findings, the model below is specified in this study.

Model I

$\mathrm{CBC} / \mathrm{GDP}=\mathrm{f}(\mathrm{NBB}, \mathrm{CBDL}, \mathrm{LIQR}, \mathrm{OPE}, \mathrm{DR})$

Transforming equation 1 into a testable form, we have;

CBC/GDP

$$
=\beta_{0}+\beta_{1} \mathrm{NBB}+\beta_{2} \mathrm{CBDL}+\beta_{3} \mathrm{LIQR}+\beta_{4} \mathrm{OPE}+\beta_{5} D R+\mu 2
$$

\section{Where;}

$\begin{array}{lll}\text { CBC/GDP } & = & \text { Percentage of Commercial Bank Credit to Gross Domestic Product( \% GDP ) } \\ \text { NBB } & = & \text { Number of Commercial Banks Branches } \\ \text { CBDL } & = & \text { Lommercial Banks Deposit Liabilities } \\ \text { LIQR } & = & \text { Operational Refficiency of Managementproxied by total cost to total revenue } \\ \text { OPE } & = & \text { Deposit Rate } \\ \text { DR } & = & \text { Regression Intercept } \\ \beta_{0} & = & \text { Coefficient of the independent variables to the }\end{array}$

Dependent variable

$$
\mu \quad=\quad \text { Error term }
$$

\section{Model II}

$$
\mathrm{CBC} / \mathrm{GDP}=\mathrm{f}(\mathrm{MPR}, \mathrm{TBR}, \mathrm{RINTR}, \mathrm{FD}, \mathrm{G}-\mathrm{M} 2)
$$

\begin{tabular}{|c|c|c|}
\hline $\mathrm{CBC} / \mathrm{GDP}$ & \multirow{2}{*}{\multicolumn{2}{|c|}{$=\beta_{0}+\beta_{1} \mathrm{MPR}+\beta_{2} \mathrm{TBR}+\beta_{3} \mathrm{RINTR}+\beta_{4} \mathrm{~F} D+\beta_{6} \mathrm{G}-M 2+\mu$}} \\
\hline \multirow[b]{2}{*}{ Percent of Commercial Banks Credit to Gross Domestic Product (\% GDP) } & & \\
\hline & \multirow{4}{*}{$\begin{array}{l}= \\
= \\
= \\
\text { R }\end{array}$} & Percent of Commercial Banks Credit to Gross Domestic Product ( \% GDP) \\
\hline MPR & & Monetary Policy Rate \\
\hline TBR & & Treasury Bill Rate \\
\hline RINTR & & Real Interest Rate \\
\hline FD & $=$ & Financial Sector Development \\
\hline G-M2 & $=$ & Growth of Broad Money Supply \\
\hline$\beta_{0}$ & $=$ & Regression Intercept \\
\hline$\beta_{1}-\beta_{6}$ & $=$ & of the independent variables to the \\
\hline \multicolumn{3}{|c|}{ Dependent variable } \\
\hline & $=$ & Error term \\
\hline
\end{tabular}

Transforming equation 3 into a testable form, we have;

Model III

$\mathrm{CBC} / \mathrm{GDP}=\mathrm{f}(\mathrm{RGDP}, \mathrm{INFR}, \mathrm{EXR}, \mathrm{OPE}, \mathrm{PEX})$

Transforming equation 4 into a testable form, we have;

$\begin{array}{lll}\mathrm{CBC} / \mathrm{GDP} & =\beta_{0}+\beta_{1} \mathrm{RGDP}+\beta_{2} \mathrm{INFR}+\beta_{3} \mathrm{EXR}+\beta_{4} \mathrm{OPE}+\beta_{5} \mathrm{PEX}+\mu \\ \text { Where; } & = & \text { Percent of Commercial Banks Credit to Gross Domestic Product } \\ \text { CBC/GDP } & = & \text { Real Gross Domestic Product } \\ \text { RGDP } & = & \text { Inflation Rate } \\ \text { INFR } & = & \text { Exchange Rate } \\ \text { EXR } & = & \text { Openness of the Economy } \\ \text { OPE } & = & \text { Public Expenditure }\end{array}$




$\begin{array}{lll}\beta_{0} & = & \text { Regression Intercept } \\ \beta_{1}-\beta_{5} & = & \text { Coefficient of the independent variables to the }\end{array}$

Dependent variable

$\mu \quad=\quad$ Error term

A-Priori Expectation

Model I: $\beta_{1}, \beta_{2}, \beta_{4}, \beta_{5}>0 \quad \beta_{3}<0$

Model II: $\beta_{1}, \beta_{2}, \beta_{4}, \beta_{5}>0 \beta_{3}<0$

Model III: $\beta_{1}, \beta_{2}, \beta_{4}, \beta_{5}>0 \beta_{3}<0$

\section{Estimation Procedure}

\section{Unit Root Test}

Most of time series have unit root as demonstrated by many studies including Nelson and Plosser (1982), Stock and Watson (1988) and Campbell and Peron (1991). Therefore, their means of variance of such time series are not independent of time. Conventional regression technique based on non-stationary time series produce spurious regression and statistic may simply indicate only correlated trends rather true relationship Granger and Newbold (1974). Spurious regression can be detected in regression model by low Durbin Watson and relatively moderate $\mathrm{R}^{2}$.

Therefore, to distinguish between correlation that arises from share trend and one associated with an underlying causal relationship; we use both the Augmented Dickey fuller (Dickey and Fuller, 1979, 1981)

$$
X_{t}=\mu+\Theta X_{t-1}+\varepsilon_{t}
$$

The null hypotheses for the ADFstatistic test are $\mathrm{H}_{0}$.Non stationary (unit root) and $\mathrm{H}_{0}$ : Stationary respectively

\section{Co-integration}

To search for possible long run relationship amongst the variables, we employ the Johansen and Juselius (1990) approach. Thus, the study constructed a p-dimensional $(4 \times 1)$ vector auto regression model with Gaussian errors that can be expressed by its first differenced error correction form as

$$
\Delta Y_{t}=\Gamma_{1} \Delta Y_{t-1}+\Gamma_{2} \Delta Y_{t-2}+\ldots . .+\Gamma_{k-1} \Delta Y_{t-k+1}-\Pi Y_{t-1}+\mu+\varepsilon_{t}
$$

Where $\mathrm{Y}_{\mathrm{t}}$ are the data series studied,

$$
\varepsilon_{t} \text { is i. i. } \mathrm{d}, \mathrm{N}(0, \Sigma) \Gamma_{i}+-1+\mathrm{A}_{1}+\mathrm{A}_{1}+\mathrm{A}_{2}+\mathrm{A}_{3}+\ldots \ldots .+\mathrm{A}_{\mathrm{i}} \text { for } \mathrm{i}=1,2,3 \ldots \ldots \ldots, \mathrm{k}-1, \Pi=\mathrm{I}-\mathrm{A}_{1}-\mathrm{A}_{2}-\ldots \ldots-\mathrm{A}_{\mathrm{k}}
$$

9

The $\Pi$ matrix conveys information about the long term relationship among the $\mathrm{Y}_{\mathrm{t}}$ variables studied. Hence, testing the cointegration entails testing for the rank $r$ of matrix $\Pi$ by examine whether the eigenvalues of $\Pi$ are significantly different from zero.

Johansen and Juselius (1990) proposed two tests statistics to determine the number of cointegrating vectors (or the rank of $\Pi)$, namely the trace and the maximum eigen-value ( $\lambda$-trace) is computed as;

$$
\lambda \text { trace }=-T \sum_{j=r+1}^{n} \operatorname{In}\left(1-\lambda_{j}\right) \quad 10
$$

The trace tests the null hypothesis that "at most" $\mathrm{r}$ co-integration vector, with "more than" $\mathrm{r}$ vectors being the alternative hypothesis. The maximum eigenvalue test is given as:

$$
\lambda_{\max }=-\operatorname{TIn}\left(1-\lambda_{r+1}\right)
$$

It tests the null hypothesis of $r$ co-integrating vectors against the alternative hypothesis of $r+1$ co-integration vectors. In the equation (10) and (11), is the sample size and $\lambda$ is the largest canonical correlation.

\section{Granger Causality}

In case we do not find any evidence for co-integration among the variables, the specification of the Granger causality will be a vector autoregression (VAR) in the first difference form. However, if will find evidence of cointegration, there is the need to augment the Granger-type causality test model with a one period lagged error term. This is a crucial step because as noted by Engel and Granger (1987). 


$$
Y_{t}=\alpha_{o}+\sum_{i=1}^{n} \alpha_{1}^{y} Y_{t-1} \sum_{i=1}^{n} X_{a 1} X \mu
$$

and

$$
X_{t}=\beta_{o}+\sum_{i=1}^{n}{ }_{\beta 1}^{y} Y_{t-1} \sum_{i=1}^{n} X_{\beta 1} X Y_{t}
$$

\section{Error Correction Model (ECM)}

Co-integration is a prerequisite for the error correction mechanism. Since co-integration has been established, it is pertinent to proceed to the error correction model.

\section{Results and Discussion of Findings}

\begin{tabular}{|c|c|c|c|c|}
\hline Variable & Coefficient & T-Statistics & & Prob. \\
\hline CBDL & 0.944815 & 0.320126 & 2.951387 & 0.0068 \\
\hline DR & -0.073630 & 0.329448 & -0.223496 & 0.8250 \\
\hline LIQR & 0.070625 & 0.348065 & 0.202907 & 0.8408 \\
\hline NBB & -0.182644 & 0.060617 & -3.013069 & 0.0059 \\
\hline OPE & -0.115707 & 0.105006 & -1.101914 & 0.2810 \\
\hline $\mathrm{C}$ & 8.531951 & 9.269151 & 0.920467 & 0.3661 \\
\hline R2 & 0.777896 & & & \\
\hline ADJ. R2 & 0.552630 & & & \\
\hline F-STATISTICS & 4.337907 & & & \\
\hline F-PROB & 0.000890 & & & \\
\hline Durbin-Watson stat & 2.401563 & & & \\
\hline EXR & 0.082146 & 0.024577 & 3.342392 & 0.0026 \\
\hline$\overline{\text { INFR }}$ & 0.033077 & 0.056301 & 0.587491 & 0.5621 \\
\hline OPE & -0.217520 & 0.076679 & -2.836782 & 0.0089 \\
\hline PEX & -0.111390 & 0.060587 & -1.838514 & 0.0779 \\
\hline RGDP & 0.401942 & 0.324098 & 1.240187 & 0.2264 \\
\hline $\mathrm{C}$ & 16.33847 & 4.380158 & 3.730109 & 0.0010 \\
\hline R-squared & 0.657973 & & & \\
\hline Adjusted R-squared & 0.589567 & & & \\
\hline F-statistic & 9.618715 & & & \\
\hline Prob(F-statistic) & 0.000032 & & & \\
\hline Durbin-Watson stat & 1.059613 & & & \\
\hline FD & -0.306369 & 0.371902 & -0.823789 & 0.4178 \\
\hline G_M2 & 0.737820 & 0.298887 & 2.468555 & 0.0208 \\
\hline MPR & -0.325075 & 0.664682 & -0.489068 & 0.6291 \\
\hline RINTR & 0.074515 & 0.269627 & 0.276362 & 0.7845 \\
\hline TBR & 0.063271 & 0.496470 & 0.127442 & 0.8996 \\
\hline $\mathrm{C}$ & 9.164022 & 10.51041 & 0.871900 & 0.3916 \\
\hline R-squared & 0.335405 & & & \\
\hline Adjusted R-squared & 0.202486 & & & \\
\hline F-statistic & 2.523382 & & & \\
\hline Prob(F-statistic) & 0.055642 & & & \\
\hline Durbin-Watson stat & 0.594821 & & & \\
\hline
\end{tabular}

Table 1: Presentation of Results

Model I examined the bank specific variables and commercial domestic credit in Nigeria, an examination of the above table proved that the independent variables formulated in model I can explain 77.7 and 55.2 percent variation 
on total commercial banks credit in Nigeria while the estimated regression model proved significant from the Fstatistics. Also the Durbin Watson statistics is greater than 2.0 but less than 2.5 , this prove the presence of serial autocorrelation. The F-statistics and the F-probability proves that commercial bank deposit liability and liquidity are statistically significant while other variables in the model are statistically not significant. In ascertaining the direction of the relationship, the study found that commercial banks deposit liability and liquidity ratio have positive impact on commercial bank loans and advances while deposit rate, number of commercial bank branches and operational efficiency of the industry have negative impact on the dependent variable. The positive effect of the deposit liability confirm the a-priori expectation of the results and justifies various reforms formulated in the Nigerian banking sector to effectively intermediate between the deficits and surplus the economic unit such as the rural banking scheme in 1975, the universal banking scheme in 2001-2004 the banking sector consolidation and recapitalization in 2004/2005. However, the negative impact of liquidity reserve confirms the a-priori expectation of the results. According to Nwankwo (1998) there is inverse relationship between liquidity and earning assets of commercial banks. This is what Toby (2004) described as optimal liquidity and lending position. The negative impact of deposit rate, number of bank branches and operational efficiency is contrary to our expectations as the variables are expected to have a positive impact on the dependent variable. The negative impact could be traced to poor banking habits and high banking density as noted in Akani and Lucky (2018).

Model II which examined the effect of macroeconomic variables on commercial bank credit found that the independent variables can explain 65.7 and 55.9 variations on total commercial bank credits within the period under study. This is justified by the validity of the F-statistics and probability. However, the Durbin Watson explains variation justifies the presence of serial autocorrelation in the model. Further, the coefficient of the independent variable which measures the direction of the relationship found that all the independent variables have positive relationship with the dependent variable except openness of the economy and public expenditure. However, Exchange rate, openness of the economy and public expenditure are statistically significant while inflation rate and real GDP are statistically not significant. The positive effect of the variables confirm various macroeconomic policy reforms such as financial sector deregulation with the objective of increasing the operational efficiency of business institutions. It also agreed with the findings of Akani and Onyema (2017). The negative of the variables is contrary to our expectation and could be traced to policies such as the treasury single account system and other macroeconomic instability.

Model III which examined the effect of monetary policy variables on commercial banks loans and advances found that the independent variables can explain 33.5 and 20.2 percent while the F-statistics validates the model. The coefficient of the variables found that financial sector development and monetary policy rate negatively related to total commercial banks loans and advances while growth of money supply, real interest rate and Treasury bill rate positively relates to the dependent variable. The model found that growth of broad money supply is statistically significant while other variables in the model are statistically not significant. The positive effect of the variables confirms our a-priori expectation. The negative impact of financial sector development and monetary policy rate is contrary to our expectation and could be traced to monetary policy shocks. The above results enable us to test for stationary of the variables using the Augmented Dickey Fuller unit root test.

Table 2: Unit Root Test Summary Results at First Difference

\begin{tabular}{|c|c|c|c|c|c|c|}
\hline \multirow[t]{2}{*}{ Variable } & \multirow[t]{2}{*}{ ADF Statistics } & \multicolumn{3}{|r|}{ Mackinnon } & \multirow[t]{2}{*}{ Prob. } & \multirow[t]{2}{*}{ Order Of Intr. } \\
\hline & & $1 \%$ & $5 \%$ & $10 \%$ & & \\
\hline $\mathrm{CBC} / \mathrm{GDP}$ & -4.241819 & -3.689194 & -2.971853 & -2.625121 & 0.0026 & $1(1)$ \\
\hline LIQR & -1.429812 & -3.679322 & -2.986225 & -2.622989 & 0.0001 & $1(1)$ \\
\hline NBB & -9.109359 & -3.699871 & -2.976263 & -2.627420 & 0.0000 & $1(1)$ \\
\hline $\mathrm{OPE}$ & -6.935697 & -3.808546 & -2.971853 & -2.625121 & 0.0000 & $1(1)$ \\
\hline \multicolumn{7}{|c|}{ Unit Root Test Summary Results at First Difference } \\
\hline $\mathrm{CBC} / \mathrm{GDP}$ & -5.111894 & -3.752946 & -2.998064 & -2.638752 & 0.0000 & $1(1)$ \\
\hline INFR & -5.818042 & -3.679322 & -2.967767 & -2.622989 & 0.0000 & $1(1)$ \\
\hline OPE & -6.358758 & -3.699871 & -2.976263 & -2.627420 & 0.0000 & $1(1)$ \\
\hline
\end{tabular}




\begin{tabular}{ccccccc}
\hline EXR & -7.098366 & -3.679322 & -2.967767 & -2.622989 & 0.0000 & $1(1)$ \\
\hline CBC /GDP & -4.241819 & -3.689194 & -2.971853 & -2.638752 & 0.0000 & $1(1)$ \\
\hline FD & -5.101366 & -3.679322 & -2.967767 & -2.625121 & 0.0026 & $1(1)$ \\
\hline G_M2 & -5.431477 & -3.689194 & -2.971853 & -2.622989 & 0.0003 & $1(1)$ \\
\hline MPR & -6.663459 & -3.699871 & -2.976263 & -2.625121 & 0.0001 & $1(1)$ \\
\hline RINTR & -8.036245 & -3.699871 & -2.976263 & -2.627420 & 0.0000 & $1(1)$ \\
\hline TBR & -6.055479 & -3.689194 & -2.971853 & -2.627420 & 0.0000 & $1(1)$ \\
\hline
\end{tabular}

Source: Extracts from E-view (2018)

Having identified the presence of the serial autocorrelation, we test for unit root. From the table above, we found that all the variables are stationary at first difference which implies that the variables are integrated in the order of 1(1). We accept alternate hypothesis, we therefore proceeds to co-integration test ascertain the presence of long run relationship or not

Table 3: Johansen Co-Integration Test Results: Trace Statistics

\begin{tabular}{|c|c|c|c|c|c|}
\hline $\begin{array}{l}\text { Hypothesized } \\
\text { No. of CE(s) }\end{array}$ & Eigen value & Trace Statistics & $\begin{array}{c}0.05 \\
\text { Critical Value } \\
\end{array}$ & Prob.** & Decision \\
\hline None $*$ & 0.856928 & 136.3457 & 95.75366 & 0.0000 & Reject $\mathrm{H}_{0}$ \\
\hline At most $1 *$ & 0.680575 & 79.95784 & 69.81889 & 0.0062 & reject $\mathrm{H}_{0}$ \\
\hline At most 2 & 0.517663 & 46.86213 & 47.85613 & 0.0618 & reject $\mathrm{H}_{0}$ \\
\hline At most 3 & 0.444551 & 25.71788 & 29.79707 & 0.1374 & Accept $\mathrm{H}_{0}$ \\
\hline At most 4 & 0.248740 & 8.666488 & 15.49471 & 0.3971 & Accept $\mathrm{H}_{0}$ \\
\hline At most 5 & 0.012758 & 0.372370 & 3.841466 & 0.5417 & Accept $\mathrm{H}_{0}$ \\
\hline \multicolumn{6}{|l|}{ Model II } \\
\hline None $*$ & 0.814542 & 118.4784 & 95.75366 & None $*$ & Reject $\mathrm{H}_{0}$ \\
\hline At most 1 & 0.573135 & 69.61551 & 69.81889 & At most 1 & reject $\mathrm{H}_{0}$ \\
\hline At most 2 & 0.497174 & 44.92817 & 47.85613 & At most 2 & reject $\mathrm{H}_{0}$ \\
\hline At most 3 & 0.398347 & 24.99033 & 29.79707 & At most 3 & Accept $\mathrm{H}_{0}$ \\
\hline At most 4 & 0.273015 & 10.25617 & 15.49471 & At most 4 & Accept $\mathrm{H}_{0}$ \\
\hline At most 5 & 0.034213 & 1.009532 & 3.841466 & At most 5 & Accept $\mathrm{H}_{0}$ \\
\hline \multicolumn{6}{|l|}{ Model III } \\
\hline None * & 0.833949 & 130.4656 & 95.75366 & 0.0000 & Reject HO \\
\hline At most $1 *$ & 0.683583 & 78.39719 & 69.81889 & 0.0088 & reject $\mathrm{H}_{0}$ \\
\hline At most 2 & 0.584981 & 45.02707 & 47.85613 & 0.0900 & reject $\mathrm{H}_{0}$ \\
\hline At most 3 & 0.269891 & 19.52360 & 29.79707 & 0.4558 & Accept $\mathrm{H}_{0}$ \\
\hline At most 4 & 0.234638 & 10.40132 & 15.49471 & 0.2511 & Accept $\mathrm{H}_{0}$ \\
\hline At most 5 & 0.087219 & 2.646533 & 3.841466 & 0.1038 & Accept $\mathrm{H}_{0}$ \\
\hline
\end{tabular}

Source: Extracts from E-view (2018)

Using the Johansen co-integration test, the above table 3.1, the results found that there is one co-integrating equation in model I and model III but no co-integrating equation in model II. The presence of co-integrating equation in model I and III is expected and in line with a prior expectation and implies the presence of long run relationship between bank specific variables and Total commercial banks loans and advances and monetary policy variables and total commercial banks loans and advances. The absence of co-integrating equation in model II is contrary to our expectation and could be trade to macroeconomic challenges such as business cycle. The inability of the above result to give us the direction of long run relationship enable us to test for normalized co-integration relationship.

Table 4: Normalized Co-integrating Equation

\begin{tabular}{lccccc}
\hline Model I & \multicolumn{5}{l}{} \\
\hline CBC_GDP & CBDL & DR & LIQR & NBB & OPE \\
\hline 1.000000 & -0.207833 & 0.397391 & 4.038972 & 0.179184 & -1.151830 \\
\hline & $(0.30775)$ & $(0.31598)$ & $(0.55580)$ & $(0.06388)$ & $(0.16727)$ \\
\hline
\end{tabular}




\begin{tabular}{cccccc}
\hline Model II & \multicolumn{1}{l}{ OPE } & PEX & RGDP \\
\hline CBC_GDP & EXR & INFR & OPE & -0.038397 & -2.972428 \\
\hline 1.000000 & -0.123970 & -0.375509 & 0.443366 & $(0.05577)$ & $(0.35682)$ \\
\hline & $(0.02303)$ & $(0.05699)$ & $(0.07302)$ & & \\
\hline Model III & & & & TBR \\
\hline CBC_GDP & FD & G_M2 & MPR & RINTR & -9.716535 \\
\hline 1.000000 & 4.858640 & -6.101998 & -0.573168 & 8.894031 & $(1.63751)$ \\
\hline & $(1.21036)$ & $(1.33026)$ & $(2.06855)$ & $(1.00374)$ & \\
\hline
\end{tabular}

Source: Extracts from E-view (2018)

From model I, the study found that deposit liabilities and openness of the economy have negative long run relationship with the dependent variable while deposit rate, liquidity and number of bank branches have positive long run relationship. Model II found that exchange rate, inflation rate, public expenditure and real gross domestic products have negative relationship with the dependent variable while openness of the economy have positive impact on the dependent variable.

It is evidenced in model III that growth of money supply, momentary policy rate and treasury bill rate have negative long run while financial sector development and real interest rate have positive long run relationship with total loans and advances of commercial banks.

Table 5: Parsimonious Error Correction Results Model I

\begin{tabular}{|c|c|c|c|c|c|}
\hline & Variable & Coefficient & Std. Error & t-Statistic & Prob. \\
\hline & $\mathrm{C}$ & -0.141512 & 1.067818 & -0.132524 & 0.8966 \\
\hline & D(CBC_GDP(-1)) & 0.708665 & 0.322713 & 2.195958 & 0.0468 \\
\hline & $\mathrm{D}(\mathrm{CBDL}(-1))$ & 0.488425 & 0.510527 & 0.956707 & 0.3562 \\
\hline & $\mathrm{D}(\mathrm{CBDL}(-2))$ & 0.343939 & 0.633565 & 0.542863 & 0.5964 \\
\hline & $\mathrm{D}(\mathrm{CBDL}(-3))$ & -0.273246 & 0.584257 & -0.467681 & 0.6478 \\
\hline & $\mathrm{D}(\mathrm{DR}(-1))$ & 0.047427 & 0.553806 & 0.085639 & 0.9331 \\
\hline & $\mathrm{D}(\mathrm{DR}(-2))$ & 0.229004 & 0.440427 & 0.519959 & 0.6118 \\
\hline & $\mathrm{D}(\mathrm{DR}(-3))$ & 0.405319 & 0.446344 & 0.908086 & 0.3804 \\
\hline & $\mathrm{D}(\operatorname{LIQR}(-1))$ & -0.454314 & 0.461854 & -0.983675 & 0.3432 \\
\hline & $\mathrm{D}(\mathrm{NBB}(-1))$ & 0.076272 & 0.069359 & 1.099667 & 0.2914 \\
\hline & $\mathrm{D}(\mathrm{NBB}(-2))$ & 0.009103 & 0.069192 & 0.131561 & 0.8973 \\
\hline & $\mathrm{D}(\mathrm{OPE}(-1))$ & 0.097118 & 0.113525 & 0.855474 & 0.4078 \\
\hline & $\mathrm{D}(\mathrm{OPE}(-2))$ & -0.060787 & 0.149747 & -0.405934 & 0.6914 \\
\hline & ECM(-1) & -0.562017 & 0.306053 & -1.836339 & 0.0893 \\
\hline & R-squared & 0.442772 & F-statistic & & 0.794598 \\
\hline & Adjusted R-squared & -0.114456 & Prob(F-statistic) & & 0.657690 \\
\hline & & \multicolumn{3}{|c|}{ Durbin-Watson stat } & 1.931567 \\
\hline \multicolumn{6}{|c|}{ Model II } \\
\hline & $\mathbf{C}$ & 2.043938 & 1.053284 & 1.940538 & 0.0727 \\
\hline & D(CBC_GDP(-1)) & 0.562908 & 0.225122 & 2.500456 & 0.0254 \\
\hline & $\mathrm{D}(\mathrm{EXR}(-1))$ & -0.038479 & 0.079060 & -0.486711 & 0.6340 \\
\hline & $\mathrm{D}(\mathrm{EXR}(-2))$ & -0.042698 & 0.075722 & -0.563882 & 0.5818 \\
\hline & $\mathrm{D}(\operatorname{EXR}(-3))$ & -0.143669 & 0.070481 & -2.038403 & 0.0609 \\
\hline & D(INFR(-1)) & -0.025638 & 0.048227 & -0.531606 & 0.6033 \\
\hline & $\mathrm{D}(\mathrm{OPE}(-2))$ & -0.059369 & 0.096083 & -0.617901 & 0.5466 \\
\hline & $\mathrm{D}(\mathrm{OPE}(-3))$ & -0.091805 & 0.111644 & -0.822302 & 0.4247 \\
\hline & $\mathrm{D}(\operatorname{PEX}(-1))$ & 0.171279 & 0.075279 & 2.275251 & 0.0391 \\
\hline & $\mathrm{D}(\operatorname{PEX}(-2))$ & 0.040041 & 0.069050 & 0.579885 & 0.5712 \\
\hline & $\mathrm{D}(\operatorname{PEX}(-3))$ & 0.057348 & 0.075812 & 0.756449 & 0.4619 \\
\hline
\end{tabular}




\begin{tabular}{|c|c|c|c|c|}
\hline $\mathrm{D}(\mathrm{RGDP}(-1))$ & -0.270962 & 0.206818 & -1.310150 & 0.2112 \\
\hline $\operatorname{ECM}(-1)$ & -0.795299 & 0.252028 & -3.155597 & 0.0070 \\
\hline R-squared & 0.582549 & \multicolumn{2}{|l|}{ F-statistic } & 1.628070 \\
\hline Adjusted R-squared & 0.224733 & \multicolumn{2}{|l|}{ Prob(F-statistic) } & 0.190805 \\
\hline & & \multicolumn{2}{|l|}{ Durbin-Watson stat } & 1.934872 \\
\hline \multicolumn{5}{|c|}{ Model III } \\
\hline $\mathrm{C}$ & 0.249340 & 0.584395 & 0.426663 & 0.6757 \\
\hline D(CBC_GDP(-1)) & 0.331146 & 0.171123 & 1.935138 & 0.0721 \\
\hline $\mathrm{D}(\mathrm{FD})$ & -0.763798 & 0.169172 & -4.514913 & 0.0004 \\
\hline $\mathrm{D}(\mathrm{FD}(-1))$ & -0.154201 & 0.188692 & -0.817211 & 0.4266 \\
\hline $\mathrm{D}(\mathrm{FD}(-2))$ & -0.112717 & 0.180436 & -0.624694 & 0.5416 \\
\hline $\mathrm{D}\left(\mathrm{G} \_\mathrm{M} 2\right)$ & 0.301395 & 0.148708 & 2.026754 & 0.0608 \\
\hline $\mathrm{D}(\mathrm{MPR})$ & 0.006336 & 0.177273 & 0.035744 & 0.9720 \\
\hline $\mathrm{D}(\mathrm{MPR}(-1))$ & 0.309556 & 0.292876 & 1.056953 & 0.3073 \\
\hline $\mathrm{D}(\mathrm{MPR}(-2))$ & 0.246760 & 0.281118 & 0.877782 & 0.3939 \\
\hline D(RINTR) & -0.221470 & 0.188584 & -1.174388 & 0.2585 \\
\hline D(RINTR(-1)) & -0.372632 & 0.211311 & -1.763429 & 0.0982 \\
\hline $\mathrm{D}(\operatorname{TBR}(-2))$ & 0.500065 & 0.223421 & 2.238215 & 0.0408 \\
\hline $\mathrm{ECM}(-1)$ & -0.427213 & 0.127072 & -3.361979 & 0.0043 \\
\hline R-squared & 0.700118 & \multicolumn{2}{|l|}{ F-statistic } & 2.918309 \\
\hline Adjusted R-squared & 0.460213 & \multicolumn{2}{|c|}{ Prob(F-statistic) } & 0.026596 \\
\hline & \multicolumn{3}{|c|}{ Durbin-Watson stat } & 1.901181 \\
\hline
\end{tabular}

Source: Extracts from E-view (2018)

From the error correction result, model I found a speed of adjustment of 56.2 percent, model II found a speed of adjustment of 79.5 percent while model III found a speed of adjustment of 42.7 percent. The independent variables show positive and negative impact of the variables on the dependent variables at various lags. However, the result shows that total commercial bank loans and advances is positive.

Table 6: Granger Causality Test

Model I

\begin{tabular}{lccc}
\hline Null Hypothesis: & Obs & F-Statistic & Prob. \\
\hline CBDL does not Granger Cause CBC_GDP & 29 & 2.15789 & 0.1375 \\
\hline CBC_GDP does not Granger Cause CBDL & & 1.62069 & 0.2187 \\
\hline DR does not Granger Cause CBC_GDP & 29 & 1.30077 & 0.2908 \\
\hline CBC_GDP does not Granger Cause DR & & 0.41874 & 0.6626 \\
\hline LIQR does not Granger Cause CBC_GDP & 29 & 1.46458 & 0.2511 \\
\hline CBC_GDP does not Granger Cause LIQR & & 2.10770 & 0.1435 \\
\hline NBB does not Granger Cause CBC_GDP & 29 & 0.44604 & 0.6454 \\
\hline CBC_GDP does not Granger Cause NBB & & 4.22038 & 0.0269 \\
\hline OPE does not Granger Cause CBC_GDP & 29 & 1.00600 & 0.3806 \\
\hline CBC_GDP does not Granger Cause OPE & & 0.74080 & 0.4873 \\
\hline
\end{tabular}

\section{Model II}

\begin{tabular}{lccc}
\hline EXR does not Granger Cause CBC_GDP & 29 & 1.23298 & 0.3092 \\
\hline CBC_GDP does not Granger Cause EXR & & 0.41550 & 0.6647 \\
\hline INFR does not Granger Cause CBC_GDP & 29 & 0.61703 & 0.5479 \\
\hline CBC_GDP does not Granger Cause INFR & & 0.40108 & 0.6740 \\
\hline OPE does not Granger Cause CBC_GDP & 29 & 1.05771 & 0.3629 \\
\hline CBC_GDP does not Granger Cause OPE & & 1.69627 & 0.2046 \\
\hline PEX does not Granger Cause CBC_GDP & 29 & 4.51464 & 0.0217 \\
\hline
\end{tabular}




\begin{tabular}{lccc}
\hline CBC_GDP does not Granger Cause PEX & 0.38882 & 0.6820 \\
\hline RGDP does not Granger Cause CBC_GDP & 29 & 0.06756 & 0.9348 \\
\hline CBC_GDP does not Granger Cause RGDP & & 1.89492 & 0.1721 \\
\hline
\end{tabular}

\section{Model III}

\begin{tabular}{lccc}
\hline FD does not Granger Cause CBC_GDP & 29 & 11.8474 & 0.0003 \\
\hline CBC_GDP does not Granger Cause FD & & 0.58076 & 0.5671 \\
\hline G_M2 does not Granger Cause CBC_GDP & 29 & 5.28936 & 0.0125 \\
\hline CBC_GDP does not Granger Cause G_M2 & & 0.78999 & 0.4653 \\
\hline MPR does not Granger Cause CBC_GDP & 29 & 2.56373 & 0.0979 \\
\hline CBC_GDP does not Granger Cause MPR & & 0.25737 & 0.7752 \\
\hline RINTR does not Granger Cause CBC_GDP & 29 & 0.08543 & 0.9184 \\
\hline CBC_GDP does not Granger Cause RINTR & & 0.51837 & 0.6020 \\
\hline TBR does not Granger Cause CBC_GDP & 29 & 0.38331 & 0.6857 \\
\hline CBC_GDP does not Granger Cause TBR & & 0.35358 & 0.7058 \\
\hline
\end{tabular}

Source: Extracts from E-view (2018)

Model I found that the variable have no causal relationship except a unidirectional relationship from commercial banks loans and advances to number of commercial banks branches. Model II found also that there is no causal relationship among the variable's except a unidirectional relationship from public expenditure to commercial banks loans and advances while model III found a unidirectional relationship from financial development to financial loans and advances and a unidirectional relationship between growth of money supply to commercial banks loans and advances. Other variables in the model have no causal relationship.

\section{Conclusion}

Commercial banks remain dominant in the banking system in terms of their shares of total assets and deposit liabilities. Their total loans and advances, a major component of total credits to the private sector are still on the increase in spite of the major constraints posted by the government regulations, institutional constraints and other macro-economic factors. From the bank internal variable, deposit liability and number of commercial banks branches determine commercial banks loans and advances while other variables in the model does not determine commercial loans and advances. From model II, the study concludes that exchange rate, openness of the economy and public expenditure are strong determinants of commercial bank loans and advances while Real Gross Domestic Products and Inflation Rate does not determine bank loans and advances. Model III found that growth of money supply determine commercial bank loans and advances while other variables in the model does not determine commercial bank loans and advances.

6. Recommendation

There should be closer consultation and cooperation between commercial banks and the regulatory authorities so that the effect of regulatory measure on commercial banks will be taken into account at the stage of policy formulation andNigerian commercial banks should ensure good planning which encompasses budgeting, reviews and incentives.

Banks should try as much as possible to strike a balance in their loan pricing decisions. This will help them to be able to cover cost associated with lending and at the same time, maintain good banking relationship with their borrowers and macroeconomic policies should be properly formulated to encourage bank lending.

7. Policy Implication

In view of the nexus between commercial banks credit to the domestic economy of Nigeria within the period under review and considering the strong relationship that exist between banks specific variables, monetary variables and macroeconomic variables and commercial banks credit to domestic to the economy. Therefore, there is need to strengthening and allow the interplay of regulatory cum supervisory framework to achieve the desire results.

References

Acha, G. (2011). Does bank financial intermediation causes growth in developing Economies, the Nigerian Experience. Interbond business and Management, 3 (1), 156-161.

Ahiawodzi, A. K., \&Sackey, F. G. (2013).Determinants of credit rationing to the private sector in Ghana. African Journal of Business Management, 7(38), 38-64. 
Akani H. W.,\&Onyema, J.I. (2017).Determinants of Credit Growth in Nigeria: A Multi-Dimensional Analysis. Journal of Economics and Sustainable Development 8(20), 201-215.

Alhanusoglou, Panayiotis P., Delis, Mathaaos D. and Sikoras Christos K (2008). Determinants of bank Profitability in South Eastern European Regional -MPRA Paper no 10274 Posted 03. September.

Bagehot S. (1983). Profitability and its implication, $2^{\text {nd }}$ edition, pg $44-57$ Homewood: Richard Irvin Publication.

Bbenkele, E. K. (2007). An investigation of small and medium enterprises perceptions towards services offered by commercial banks in South Africa. African journal of accounting, economics, finance and banking research, $1(1)$.

Behr, P., Norden, L., \& Noth, F. (2013).Financial constraints of private firms and bank lending behavior. Journal of Banking and Finance, 37(9), 3472-3485.

BOFIA (1998) Requirement for Investment and Lending behaviour in Nigeria banking industry.

Buchheit, L. C. (1992). Syndicated Loans and the Art of Happiness .Int'l Fin. L. Rev., 11, 7.

Chizea G., (1994) .Analysis of Monetary and Fiscal Policies, broader perspectives, $2^{\text {nd }}$ edition, pg 12-24, BBT Press.

Chodecal D, (2004).Impact of lending policy on banking industry in Nigeria. Journal, 7(4), 12-22.

Chodechai, S. (2004).Determinants of bank lending in Thailand. An empirical examination for the years 19921996.Unpublished Thesis.

Cole, R. A. (1998). The importance of relationships to the availability of credit. Journal of Banking \& Finance, 22(6), 959-977.

Constant, F., \&Ngomsi, A. (2012).Determinants of bank long-term lending behavior in the Central African Economy and Monetary Community (CEMAC).Review of Economics and Finance, 2, 107-114.

Daniel, B. C., \& Jones, J. B. (2007).Financial liberalization and banking crises in emerging economies. Journal of International Economics, 72(1), 202-221

Davis and Zhu (2005). Commercial Property Price and bank Performance, 3(3), 11-23.

Demirguc-Kunt, A., Detragiache.E., \&Tressel, T. (2008).Banking on the principles: Compliance with Basel Core Principles and bank soundness. Journal of Financial Intermediation, 17(4), 511-542.

Eichengreen, B., \& Rose, A. K. (1998).Staying afloat when the wind shifts: External factors and emerging-market banking crises (No. w6370).National Bureau of Economic Research.

Engle R.F., \& Granger, C.W.J. (1987).Co-integration and Error Correlation: Representation, Estimation and Testing Eonometrics, 55(14), 251-276.

Ezirim F (2005). Impact of bank lending on liquidity of banks in Nigeria.Journal 2(6), 44-56.

Gilbert, E., Calitz, E., \& Du Plessis, S. (2009). Prudential regulation, its international background and the performance of the banks a critical review of the South African environment since 1970. South African Journal of Economic History, 24(2), 43-81.

Hansen, H. and J. Rand (2006).On the Casual Links between FDI and Growth in Developing Countries. World Development 2(9), 21-41.

Imran, K., \&Nishat, M. (2013). Determinants of bank credit in Pakistan: A supplyside approach. Economic modeling, 3(5), 384-390.

Kashyap, A. K., Rajan, R., \& Stein, J. C. (2002). Banks as liquidity providers: An explanation for the coexistence of lending and deposit-taking. The Journal of Finance, 57(1), 33-73

Kumbirai, M., \& Webb, R. (2013).A financial ratio analysis of commercial bank performance in South Africa. African Review of Economics and Finance, 2(1), 30-53

Loutskina, E. (2011). The role of securitization in bank liquidity and funding management. Journal of Financial Economics, 100(3), 663-684.

Malede, M. (2014). Determinants of Commercial Banks' Lending: Evidence from Ethiopian Commercial Banks. European Journal of Business and Management.2222-1905.

Matemilola, B. T., Bany-Ariffin, A. N., \&Muhtar, F. E. (2015). The impact of monetary policy on bank lending rate in South Africa. Borsa Istanbul Review, 15(1), 53-59.

Meyer, L.H. (1998). The present and future roles of banks in small business finance. Journal of Banking and Finance, 22(6), 1109-1116.

Naceur, J.,\& Goaid A., (2010).Determinants of commercial bank in Nigeria, 5(2),19-29, Macmillan Publication limited.

Olokoyo, F. O. (2011). Determinants of commercial banks' lending behavior in Nigeria. International Journal of Financial Research, 2(2), 61.

Osayameh F. (1991).Lending and credit administration model for commercial banks. Nigeria Financial Review, $4(2), 55-60$ 
Panagopoulos, Y., \&Spiliotis, A. (1998). The determinants of commercial banks' lending behavior: some evidence for Greece. Journal of Post Keynesian Economics, 20(4), 649-672.

Quintyn, M. M., \& Hoelscher, M. D. S. (2003).Managing systemic banking crises(No. 224).International Monetary Fund.

Samad, A. (2004). Bahrain Commercial Bank's Performance during 1994-2001.Credit and Financial Management Review, 10(1), 33-40.

Tomak, S. (2013). Determinants of Commercial Banks' Lending Behavior: Evidence from Turkey. Asian Journal of Empirical Research, 3(8), 933-943

Uhomoibhi, T. (2008). Determinants of Bank profitability macroeconomics, Evidence from Nigeria, Deakin University, (Working paper).

\section{Copyrights}

Copyright for this article is retained by the author(s), with first publication rights granted to the journal.

This is an open-access article distributed under the terms and conditions of the Creative Commons Attribution license (http://creativecommons.org/licenses/by/4.0/). 